Developments in Russian and Post-Soviet Politics 
Also available from Macmillan Education

Patrick Dunleavy, Andrew Gamble, Ian Holliday and Gillian Peele (eds) DEVELOPMENTS IN BRITISH POLITICS 4

Peter A. Hall, Jack Hayward and Howard Machin (eds) DEVELOPMENTS IN FRENCH POLITICS

Gillian Peele, Christopher Bailey, Bruce Cain and B. Guy Peters (eds)

DEVELOPMENTS IN AMERICAN POLITICS 2

Gordon Smith, William E. Paterson, Stephen Padgett and Peter H. Merkl (eds)

DEVELOPMENTS IN GERMAN POLITICS

Stephen White, Judy Batt and Paul G. Lewis (eds) DEVELOPMENTS IN EAST EUROPEAN POLITICS

Forthcoming

Patrick Dunleavy ANALYSING BRITISH POLITICS 


\title{
Developments in Russian and Post-Soviet Politics
}

\author{
Third Edition
}

\author{
Edited by \\ Stephen White \\ Alex Pravda \\ Zvi Gitelman
}

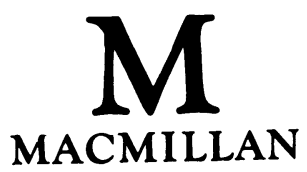


Selection and editorial matter (C) Stephen White, Alex Pravda and Zvi Gitelman 1990, 1992, 1994

Individual chapters (in order) (C) Stephen White, John P. Willerton, Thomas F. Remington, Ronald J. Hill, Robert Sharlet, Peter Rutland, Simon Clarke, Mary Buckley, Alex Pravda, Zvi Gitelman, Darrell Slider, Richard Sakwa, Leslie Holmes 1994

All rights reserved. No reproduction, copy or transmission of this publication may be made without written permission.

No paragraph of this publication may be reproduced, copied or transmitted save with written permission or in accordance with the provisions of the Copyright, Designs and Patents Act 1988, or under the terms of any licence permitting limited copying issued by the Copyright Licensing Agency, 90 Tottenham Court Road, London WIP 9HE.

Any person who does any unauthorised act in relation to this publication may be liable to criminal prosecution and civil claims for damages.

First published 1990 as Developments in Soviet Politics

Reprinted 1990, 1991

Second edition (Developments in Soviet and Post-Soviet Politics) 1992 Reprinted 1993

Third edition (Developments in Russian and Post-Soviet Politics) 1994

Published by

THE MACMILLAN PRESS LTD

Houndmills, Basingstoke, Hampshire RG21 2XS

and London

Companies and representatives

throughout the world

ISBN 978-0-333-61690-1

ISBN 978-1-349-23461-5 (eBook)

DOI 10.1007/978-1-349-23461-5

A catalogue record for this book is available from the British Library.

Typeset by Acorn Bookwork, Salisbury, Wilts 


\section{Contents}

List of Illustrations and Maps $\quad \mathbf{x}$

List of Tables and Exhibits

Preface xii

Notes on the Contributors xiii

List of Abbreviations and Terms xvi

1 Introduction: From Communism to Democracy? 1 Stephen White

The Gorbachev Agenda 3

A Presidential Republic? 11

Citizens or Subjects? 16

Part One: The Russian Political System

2 Yeltsin and the Russian Presidency John P. Willerton 25 The Political Executive in the Russian and Soviet Past 28

Yeltsin and the Russian Political Elite 33

The Executive: Institutions and Personalities 43

System-building Amidst Political Uncertainty 53

3 Representative Power and the Russian State 57

Thomas $F$. Remington

Constitutional Crisis $\quad 63$

From Soviet to Representative Democracy 65

Presidential Power $\quad 72$

Confrontation and Collapse $\quad 77$

Prospects, Constraints and Opportunities $\quad 84$ 
4 Parties and the Party System Ronald J. Hill 88

The Legacy of Communist Party Rule $\quad 88$

The Emergence of Pluralism of Interests $\quad 94$

Glasnost and the Articulation of Interests 96

The Emergence of Parties $\quad 98$

Towards a Party System $\quad 99$

The Party System and the Political System 103

Party Orientation and Party Politics 106

5 Citizen and State Under Gorbachev and Yeltsin 109

Robert Sharlet

Soviet Rule of Law Policy and Practice Under

Gorbachev $\quad 110$

Russian Constitutionalism Under Yeltsin 119

Constitution and Press in the Final Crisis of the First

Republic 125

The State and the Press During the Interregnum 126

\section{Part Two: Patterns of Public Policy}

6 The Economy: The Rocky Road from Plan to Market 131 Peter Rutland

The Origins of the Soviet Economic System 132

The Centrally Planned Economy 136

Gorbachev's Economic Reforms 138

The Struggle for Market Reform 143

1991: The Collapse of the Planned Economy 146

The Decision to Launch Shock Therapy 150

$\begin{array}{ll}\text { Conclusion } & 161\end{array}$

7 Privatisation: The Politics of Capital and Labour 162

Simon Clarke

Privatizatsiya or Prikhvatzatsiya?

The Disintegration of the Soviet System and the

Destatisation of Property

From Destatisation to Privatisation

First Steps in Privatisation: Russia's Managerial

Revolution

Privatisation and the Struggle for Power 
Privatisation and the Labour Collective

8 The Politics of Social Issues Mary Buckley 187 The Legacy of the Soviet State

A Changing Social Structure

Healthcare

Crime

Drugs

Prostitution

Conclusion

9 The Politics of Foreign Policy Alex Pravda 208

Public Politics

The Great Debate

The Role of Parliament

Executive Dominance

The Military

Disarray and Coordination

Trends

\section{Part Three: Post-Soviet Nations and States}

10 Nationality and Ethnicity in Russia and the Post-Soviet Republics Zvi Gitelman

The Disintegration of the USSR

The Ethnic Map of the Former USSR

Soviet Nationalities Policy: Ideology and History

Soviet Nationality Policy

Ethnopolitics in the Post-Soviet Period

Ethnopolitics in the Russian Federation

Conclusion

11 Politics Outside Russia Darrell Slider 266

The Baltic

Moldova and the Caucasus

Ukraine and Belarus

Central Asia and Kazakhstan 
viii

Military Ties

Economic Ties

Conclusion

Part Four: Conceptualising the Politics of Post-Soviet Russia

12 Russia, Communism, Democracy Richard Sakwa 287

The Russian Tradition $\quad 287$

Russia and Communism 292

Nationalism, Democracy and the West 297

Conclusion $\quad 306$

13 Normalisation and Legitimation in Postcommunist Russia 309

Leslie Holmes

On 'Normal' Politics 309

Legitimation Crisis and Post-Communism 323

Conclusions $\quad 330$

Guide to Further Reading 331

Bibliography 338

Index $\quad 355$ 


\section{List of Illustrations and Maps}

\section{Illustrations}

1.1 Trust in government, 1993

3.1 The Russian Federal Assembly, 1993

Map of the Former Soviet Union

xviii-xix 


\section{List of Tables and Exhibits}

Tables

1.1 Political interest and participation, 1988-92 17

2.1 Political spectrum of leading Russian Federation politicians and officials

2.2 Leading Russian Federation politicians and officials 36-7

3.1 Groups and factions in the Federal Assembly, $1994 \quad 83$

4.1 The CPSU in $1990 \quad 90$

4.2 The Russian political spectrum, $1993 \quad 102$

6.1 Soviet economic performance, 1971-88 135

6.2 Economic performance of the Commonwealth of Independent States, 1989-92 146

6.3 Russian prices and wages, 1991-3 154

7.1 Privatisation: the public response 184

8.1 Illness rates, medical provision and mortality in the Soviet republics, 1989-91

8.2 Health indicators in the Russian Federation, 1990-June 1993

10.1 The major Soviet nationalities, 1989

11.1 The Commonwealth of Independent States, $1994 \quad 268$

\section{Exhibits}

1.1 Russia's republics and regions (according to the 1993 Constitution)

2.1 The Russian presidency, 1993

3.1 The Russian Federal Assembly, $1993 \quad 80$ 


\section{Preface}

In our preface to the first edition of this book we explained that this was above all a guide for students, but hoped it might be considered more than 'just' a textbook. As befitted a volume on developments, we made no attempt to cover every aspect of what could still be described as the Soviet political system; our aim, then and now, was to allow ourselves a little more room in which to concentrate upon the more important changes in a rapidly evolving system, and to deal with the (often controversial) issues of interpretation to which they give rise. We also thought it proper, dealing with issues of this kind, to allow for a diversity of approach within a common framework.

As we wrote in 1990, our assumptions about Soviet politics were 'changing almost daily'. But not even we could claim to have foretold the changes with which we deal in this third edition, with the end of Communist Party rule and of the former USSR, and with privatisation, an emerging party system and (from December 1993) a strongly presidential Russian republic. This is accordingly a very different book: all of the chapters have been rewritten, most of them are entirely different, and several of the contributors as well as the subjects with which they deal are new to this edition. Our aim, however, remains the same: to offer an interpretative framework for what is now a group of political systems whose evolution - in an age of nuclear weapons and telecommunications - matters almost as much to the outside world as to their own citizens.

Once again, for this third edition, we would like to thank our chapter authors for their contributions and for their willingness to provide us with revisions almost to the point of publication so that this book can be as up-to-date as possible. We would like particularly to thank our publisher, Steven Kennedy, whose commitment to this series and to this book in particular has been a great inspiration. We hope that not just our students, but 
xii Preface

a wider circle of scholars and members of the general public, will find that the outcome justifies the effort that has been invested in it.

Stephen White

Alex Pravda

Zvi Gitelman 


\section{Notes on the Contributors}

Mary Buckley is Reader in Politics at the University of Edinburgh. Her books include Soviet Social Scientists Talking (1986), Women and Ideology in the Soviet Union (1989), Perestroika and Soviet Women (edited, 1992) and most recently Redefining Russian Society and Polity (1993).

Simon Clarke is Reader in Sociology at the University of Warwick and the author of What about the Workers? (with others, 1993). With Peter Fairbrother he has been researching the restructuring of management, industrial relations and labour organisation in Russia since 1990, in collaboration with teams of Russian researchers in four contrasting Russian regions.

Zvi Gitelman is Professor of Political Science and Judaic Studies at the University of Michigan, Ann Arbor. A specialist in Soviet and Russian political sociology and ethnic issues, his books include Jewish Nationality and Soviet Politics (1972), Public Opinion in European Socialist Systems (coedited, 1977), Becoming Israelis (1982), A Century of Ambivalence: The Jews of Russia and the Soviet Union (1988), and The Politics of Nationality and the Erosion of the USSR (edited, 1992).

Ronald J. Hill is Professor of Comparative Government at Trinity College, Dublin. His books include The Soviet Communist Party (with Peter Frank, 3rd ed., 1987), The USSR: Politics, Economics and Society (1989), Communism under the Knife: Autopsy or Surgery? (1991); he is also the author of numerous contributions to professional journals and symposia, with particular reference to local goverjnment and the CPSU, and a member of the board of the Journal of Communist Studies and Transition Politics.

Leslie Holmes has been Professor of Political Science at the University of Melbourne since 1988, and is currently acting Director of the Centre for Russian and Euro-Asian Studies. Among his many publications are Politics in the Communist World 
(1986), The End of Communist Power (1993), and a forthcoming study of Post-Communism.

Alex Pravda is a Fellow of St Antony's College and Lecturer in Politics at Oxford University, and was previously Director of the Soviet foreign policy programme at the Royal Institute of International Affairs (Chatham House). His books include Trade Unions in Communist States (with Blair Ruble, 1986), British-Soviet Relations since the 1970s (coedited, 1990), Perestroika: Soviet Domestic and Foreign Policies (coedited, 1990), and The End of the Outer Empire: Soviet-East European Relations in Transition (edited, 1992).

Thomas F. Remington is Professor of Political Science at Emory University, Atlanta. His books include Politics in the USSR (with Frederick Barghoorn, 1986), The Truth of Authority: Ideology and Communication in the Soviet Union (1988), Politics and the Soviet System (edited, 1989) and Parliaments in Transition: New Legislative Politics in the Former USSR and Eastern Europe (edited, 1994); he is also a member of the board of Russian Review.

Peter Rutland is Associate Professor in the Department of Government at Wesleyan University, Middletown, Connecticut. A specialist on Soviet and Russian political economy, his books include The Myth of the Plan (1985), The Politics of Economic Stagnation in the Soviet Union (1993) and a forthcoming study entitled Russia, Eurasia and the Global Economy.

Richard Sakwa is Senior Lecturer in the Faculty of Social Sciences at the University of Kent, Canterbury. His many publications include Soviet Politics (1989), Gorbachev and his Reforms 1985-1990 (1990) and Russian Politics and Society (1993), as well as contributions to journals and symposia. He is a member of the board of the Journal of Communist Studies and Transition Politics.

Robert Sharlet is Professor of Political Science at Union College in Schenectady, New York, and an Associate of the Harriman Institute of Columbia University. A specialist on Soviet and Russian law and politics, he has published six books of which the most recent is Soviet Constitutional Crisis: From De-Stalinization to Disintegration (1992).

Darrell Slider is Associate Professor of International Studies at the University of South Florida, Tampa. He is the author of a 
number of articles on Soviet and post-Soviet politics and is the coauthor, with Stephen White and Graeme Gill, of The Politics of Transition: Shaping a Post-Soviet Future (1993).

Stephen White is Professor and Head of the Department of Politics at the University of Glasgow. His recent books include After Gorbachev (4th ed., 1993), The Soviet Transition: From Gorbachev to Yeltsin (coedited, 1993), Developments in East European Politics (coedited, 1993), and The Politics of Transition: Shaping a Post-Soviet Future (with Graeme Gill and Darrell Slider, 1993); he is also chief editor of Coexistence and of the Journal of Communist Studies and Transition Politics.

John P. Willerton is Associate Professor of Political Science at the University of Tucson, Arizona. A specialist on Russian and post-Soviet elite politics and the policy proces, he is the author of Patronage and Politics in the USSR (1992); his other publications have appeared in Slavic Review, Soviet Studies, Studies in Comparative Communism and other journals and professional symposia. 


\section{List of Abbreviations and Terms}

\begin{tabular}{|c|c|}
\hline Apparat & Party administrative apparatus \\
\hline Apparatchik & Full-time party official \\
\hline Arbitrazh & $\begin{array}{l}\text { Tribunal system for disputes between state } \\
\text { enterprises }\end{array}$ \\
\hline birzhy & commodity exchanges \\
\hline Bolshevik & $\begin{array}{l}\text { Radical ('majority') faction of Russian } \\
\text { Social Democratic Labour (later Commu- } \\
\text { nist) Party }\end{array}$ \\
\hline $\mathrm{CC}$ & Central Committee \\
\hline CIA & Central Intelligence Agency (USA) \\
\hline CIS & Commonwealth of Independent States \\
\hline CPD & Congress of People's Deputies \\
\hline CPE & Centrally planned economy \\
\hline CPSU & Communist Party of the Soviet Union \\
\hline CSCE & $\begin{array}{l}\text { Conference on Security and Cooperation } \\
\text { in Europe }\end{array}$ \\
\hline Glasnost & Openness, publicity \\
\hline GNP & Gross national product \\
\hline Gorkom & City party committee \\
\hline $\begin{array}{l}\text { Gosagroprom } \\
\text { goskazy }\end{array}$ & $\begin{array}{l}\text { State Agroindustrial Committee } \\
\text { state orders }\end{array}$ \\
\hline Gospriemka & State quality control \\
\hline Gossnab & State Committee on Supplies \\
\hline gosudarstvennost & statehood \\
\hline Goszakaz & State order \\
\hline INF & Intermediate-range nuclear force \\
\hline gosudarstvenniki & national democrats \\
\hline Ispolkom & Executive committee of a soviet \\
\hline Kadry & Cadres, staff \\
\hline KGB & Committee of State Security \\
\hline Khozraschet & Cost accounting \\
\hline Kolkhoz & Collective farm \\
\hline
\end{tabular}


Komsomol

Krai

Menshevik

mir

NEP

Nomenklatura

Oblast

Obshchestvennik

obshchina

Okrug

Perestroika

Plenum

Podmena

PPO

pravovoe gosudarstvo

privatizatsiya

prikhvatizatsiya

Raikom

RSFSR

samizdat

Sblizhenie

Sliyanie

sobornost

sovnarkhozy

soyuz

zemstvo

USSR

Val

WTO

Zastoi
Young Communist League

Territory

Moderate (minority) faction of the Russian Social Democratic Labour (later Communist) Party peasant land commune

New Economic Policy (1921-8)

List of party-controlled posts

Region, province

Activist

community

Area, district

Restructuring

Full (plenary) meeting

Substitution, supplantation

Primary party organisation

law-based state

privatisation

asset grabbing

District party committee

Russian Soviet Federal Socialist Republic (now Russian Federation)

underground literature

Drawing together (of nationalities)

Fusion (of nationalities)

communality

economic regions

union

local government unit

Union of Soviet Socialist Republics

Gross output

Warsaw Treaty Organisation

Stagnation 


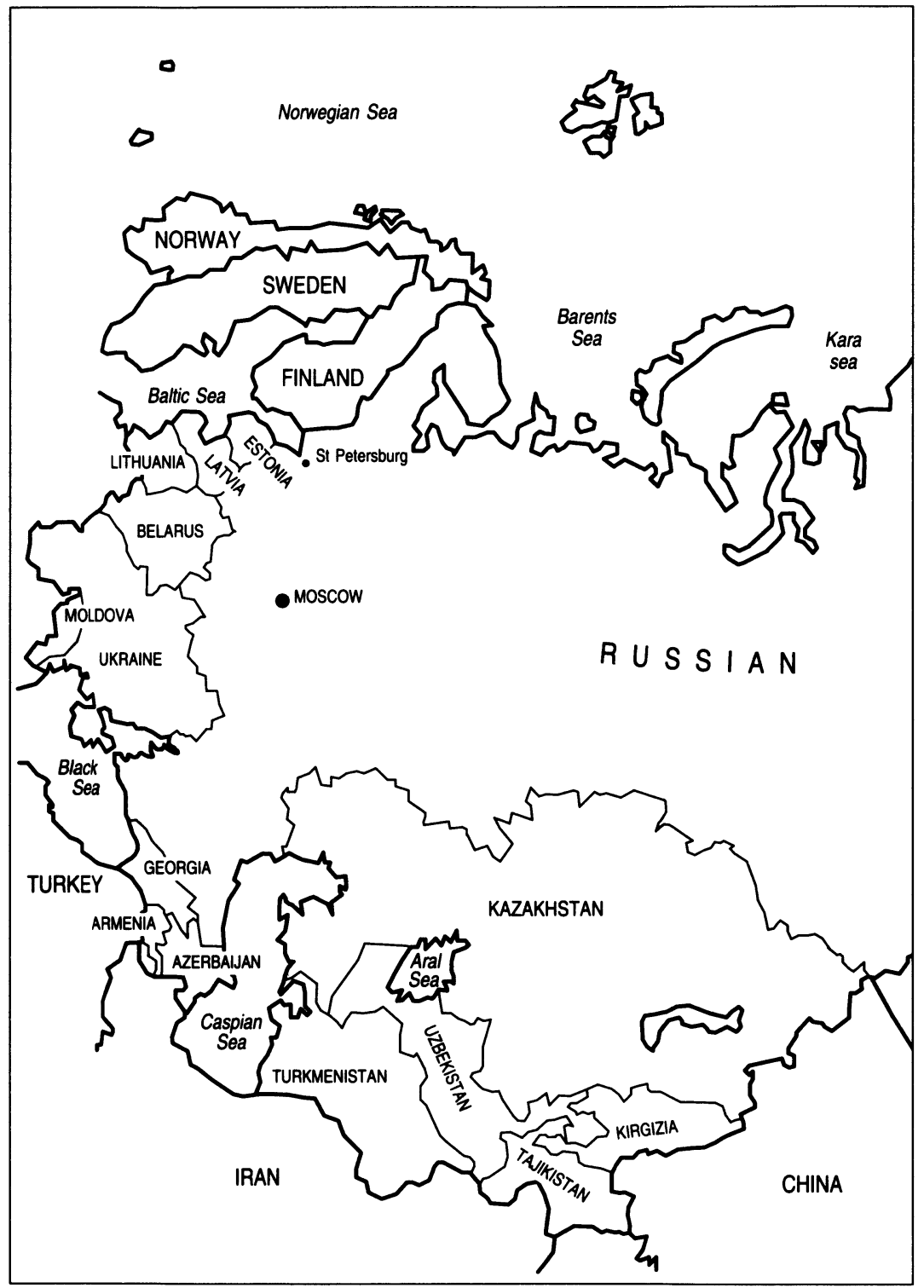

The Former 


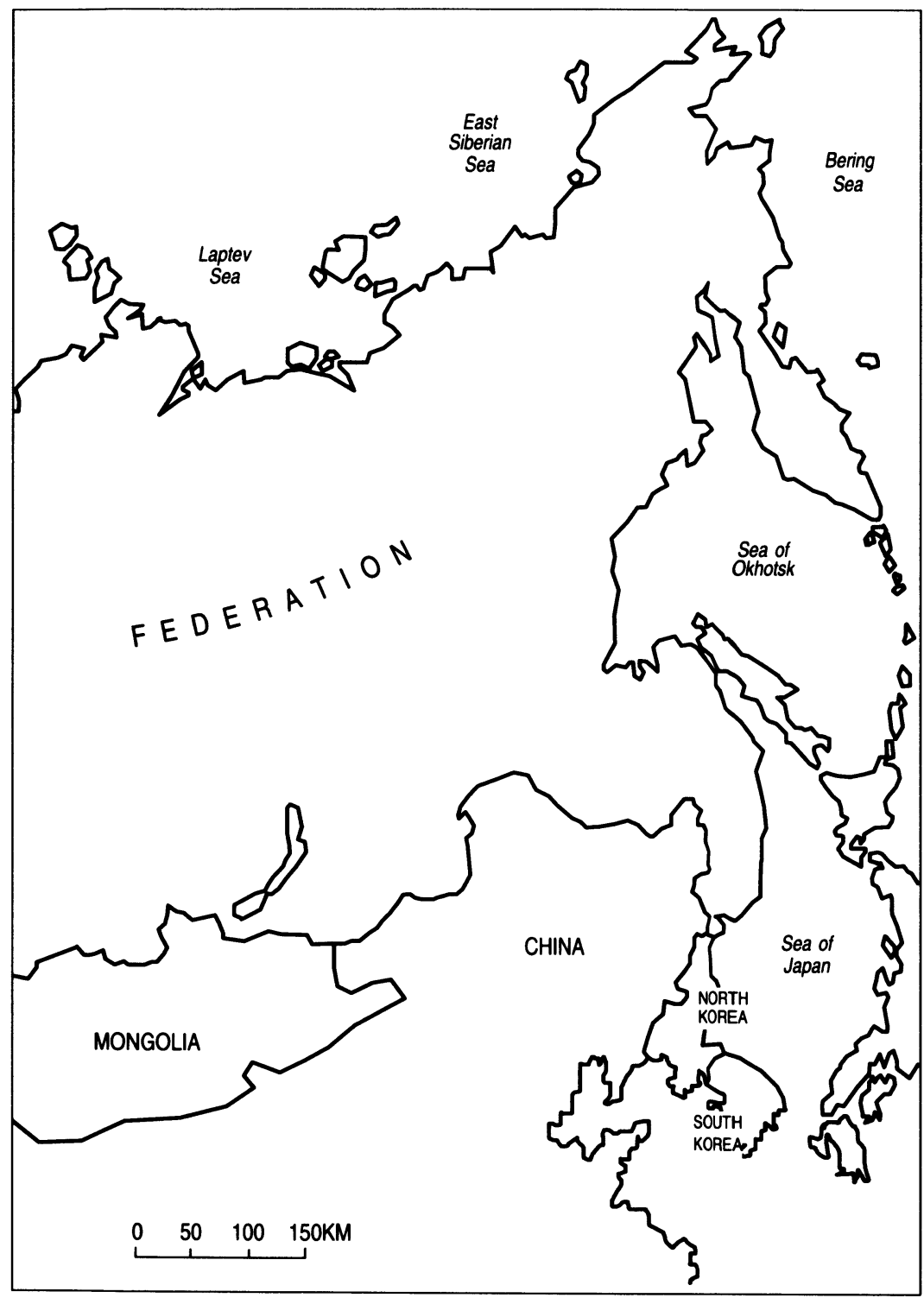

Soviet Union 